\title{
Entrepreneurial Networks Towards the Performance of Small \& Medium Manufacturing Enterprises in Kurunegala District in Sri Lanka
}

\author{
U.L. Herat ${ }^{1} \&$ W.M.H.G. Wijesinghe ${ }^{2}$ \\ ${ }^{1,2}$ Department of Business Management \\ Faculty of Business Studies \& Finance \\ Wayamba University of Sri Lanka \\ Kuliyapitiya \\ SRI LANKA \\ umangi@wyb.ac.lk ${ }^{1}$, hasithawijesinghe05@gmail.com ${ }^{2}$
}

\begin{abstract}
The Small and Medium Enterprise (SME) sector has been identified as an important strategic sector in Sri Lankan economy and it is seen as a driver of change for inclusive economic growth, regional development, employment generation and poverty reduction. Therefore, it is important to enrich the performance of SME sector in Sri Lanka. Among the SMEs in Sri Lanka, Manufacturing sector of SMEs are playing a critical role in creating wealth as it is the sector which employ large number of workforce, but the gradual decline of the annual growth rate of the Sri Lankan manufacturing sector is serious matter of concern raised by policy makers. Although there are many studies relating to entrepreneurial networks and the performance of SMEs, in Sri Lankan context there is an empirical gap. Therefore, the purpose of this study was to test a research model for investigating the impact of entrepreneurial networks on the performance of SMEs in Kurunegala district in Sri Lanka. Hence, this research focuses on critical elements such as Social networks, Professional networks and Inter-organizational networks as independent variables. The survey questionnaire was distributed to a sample of 383 SMEs in Kurunegala district. The stratified random sampling technique was used for the selection of the respondents to the sample and data analysis were done by using regression analysis. The findings proved that all the three variables positively and significantly affect the performance of SMEs. The results of this study guide the SMEs to build more entrepreneurial networks to continue to sustain and grow. It is also suggested to future researchers in the area to conduct more studies expanding the knowledge in entrepreneurial networks
\end{abstract}

Keywords: Inter-organizational Networks, Professional Networks, Social Networks, Small and Medium Manufacturing Enterprises 


\section{INTRODUCTION}

In many researchers it has been proved that the small and medium enterprises find it difficult to achieve their goals by themselves alone. In order to achieve their goals, they need support and resources from other firms Meller and Marfan (1981), Visser (1997), supporting institutions Allesch (1993), Gibb (1993), Gibb and Zoltan (1996), Lim (1994), Sarder et al. (1997), and relatives and friends Bridge et al. (1998), Birley (1985), Johannisson (1988,). Therefore, many researches have claimed that the successful achievement of SMEs are influenced by the supporting networks Donckels and Lambrecht (1995), Greve (1995), ILO (1995), Hansen (1995), Sarder, Ghosh and Rosa (1997), These network relationships allow entrepreneurs to identify opportunities and resources rapidly Cromie et al. (1994), Johannisson (1988), Sadler and Chetty (2000), Szarka (1990), Weick (1991). In this research, networks are defined as personal relationships between an entrepreneur and his 'external parties' Aldrich and Zimmer (1985), Birley (1985), Johannisson (1986, 1988).

These term "external parties" can include individuals or organizations who are not directly hired by the entrepreneur. However, Entrepreneurs develop these contacts in order to accomplish different tasks and to obtain necessary resources. In that point of view, entrepreneurial networks comprise with four major elements such as parties, resources, tasks and contacts. Entrepreneurs/managers, policy makers and academics have given their increased attention on collaborative business relationship as a means of developing small and medium enterprises (Gibb 1993, Gibb and Haas 1996). Numerous studies have identified the importance of entrepreneurial network on the performance of SMEs. Though there are numerous studies relating to entrepreneurial network and the performance of SMEs, there is an empirical gap in developing countries like Sri Lanka in identifying the impact of these entrepreneurial networks on the performance of SMEs.

\subsection{Problem Statement}

Strategic alliances, business collaborations and networks are becoming popular among the SMEs due to the competitive advantage and ability to share resources and capabilities with other firms by gaining economies of scale through joint purchase, bundling of lot size to serve large customers, joint market activities, joint product development and help in research, reduced lead time for deliver, built joint information system and reduced stocks Johnson \& Scholes (2005).

Past researchers have pointed out various factors affecting to the performance of SMEs. Welmilla, Weerakkodi and Ediriweera (2001) pointed out that there are many factors that affect the success of entrepreneurs which include age, experience and education level of the entrepreneur. In some previous studies López-García and Puente (2009) Stam and Schutjens (2005) they have identified networking as one of the 
characteristics of high growth firms (HGFs). These studies have identified networking to be key determinants of SME's growth although with inadequate empirical results. As a result, it is not clear whether or not entrepreneurial networks contribute to the performance of SMEs. It is alleged that the performance of businesses necessitates that SME owners and managers engage in networks to successfully run their business.

Many researchers may have done the researches about the entrepreneurial networks and growth of SMEs, but still there is an empirical gap in Sri Lankan context. Especially according to the annual reports of the central bank the annual growth rate of the manufacturing SMEs is gradually declined, which will ultimately can have an impact on national GDP. Therefore, it is evident that there is need for identification of the impact of entrepreneurial networks on the performance of manufacturing SMEs in Kurunegala District.

\subsection{Research Objectives}

The objectives for the present study as follow,

- To identify whether social network positively and significantly impact on the performance of manufacturing SMEs in Kurunegala District in Sri Lanka.

- To identify whether professional network positively and significantly impact on the performance of manufacturing SMEs in Kurunegala District in Sri Lanka
- To identify whether interorganizational network positively and significantly impact on the performance of manufacturing SMEs in Kurunegala District in Sri Lanka

\subsection{Contribution of the Paper}

The study aided in understanding the impact of entrepreneurial network on the performance of manufacturing SMEs in Sri Lanka. Therefore, the results of this study can be used as a reference for entrepreneurs who are interested to start their own business which will provide vision to continue to sustain and develop in the SMEs sector. Also this will provide great insights for the policy makers to prepare the policies marked relationships between individuals and business enterprises, which are mutually beneficial.

\subsection{Literature Review}

Many authors have used different definitions to define small and medium enterprises. In Sri Lankan context also the government institutions and other organizations use various measures and different definitions in order to define the SMEs. The most commonly used criteria are the number of employees, the amount of fixed investment, type of the business (i.e whether the business is informal or formal) and in which industry it operates. Lakshman et al. (1991). Organizational performance is a measure of company's success in achieving goals. Performance of a company is defined as firm's' ability to create acceptable results. As per the, 
Pfeffer and Salancik (2008) and also performance of the SME can be seen from the satisfaction of the owner/manager on profit turnover $\&$ business development.

\section{Entrepreneurial}

Networks:

According to Watson (2007) various definitions are used to define the concept of networking. These may include social capital, business networks, formal networks, informal networks and social networks. Generally, networking involves continued relationships between individuals and business enterprises, which are mutually beneficial to all parties involved Hallèn and Johanson, (2004). For firms, particularly SMEs, the networking strategy is an effective strategy for open innovation Lee, (2010). Scalera and Zazzaro (2009) define networking as a set of stable links developed for cost effective economic transactions among the network members founded on informal and formal links with mutual goals. According to Zain and Nieman, (2006) "entrepreneurial networks as the relationship between a firm's management team and employees with customers, suppliers, competitors, government agencies, distributors, bankers, families, friends, or any other party that enables it to internationalize its business activities". According to Anderson, Park and Jack (2007) "it could even be argued that it is through social relations, social interaction and networks that entrepreneurship is actually carried out." Entrepreneurial Networks are the key to open and gaining access to other resources as they ease communication among people with network ties. Anderson, (2007).

Social Networks: Social networks are mainly maintained with family, friends and acquaintances. Brown and Butler (1993), Butler and Hansen (1991), Johannisson (1986). According to Burt (1992) social networks are not fixed; they are the social context of businesses and can be activated according to different needs. To fit their enterprise needs, entrepreneurs bring both those that are closer and distant to them into their business decisions. Family members can play a critical part. Actors in a social network can be persons, groups, and collectives of organizations. Social networking is defined as the management of relationships or alliances that the individual has with others in their society Dubini and Aldrich (1991).

Professional Networks: Professional or business-oriented networks include all those individual relationships that are primarily concerned with business. Butler and Hansen (1993) suggest that a more business-focused network begins to arise during the start-up phase. This professional network, is significant for the initial stage of a business, which reflect associations with individuals and organizations that provide the more immediate needs of the new business. According to Birley and Cromie (1988) these 'professional network includes both individuals who are in the pre-existing social network, and new individuals and organizations.

Inter-organizational Networks: Inter-organizational networks are 
linkages between a business and other organizations. These can be governmental or non-governmental organizations that provide assistance for SMEs and business consultants. For a business, contacts with other organizations become critical because inter-organizational networks that include supporting agencies (government institutions, NGOs, banks, and other small business supporting institutes) and other firms (large and small firms) are a way for entrepreneurs to secure information about market relationships as well as to ensure resource channels. This improves their performance of the business and give the opportunity to compete more effectively in the industry. Aldrich, Reese, and Dubini (1989), Aldrich and Zimmer (1986). One aspect of the inter -organizational links is subcontracting Gibb (1993). Butler and Hansen's (1991) study suggest that both broad social and inter-organizational strategic networks are important for a successful start-up and ongoing competitive advantages.

\section{METHODS}

According to the Department of Statistics, population consisted with 42039 amount of manufacturing SMEs of Kurunegala district in Sri Lanka. According to Krejcie \& Morgan table 383 manufacturing SMEs were selected based on stratified sampling technique. Basically primary data collected throgh a generalized questionnire and secondary data were collected from web sites and journal articles. Data were analysed by using the regression model. Reliability was examined on all items included in the section two in the questionnaire of the present study. As a test of cronbach's alpha was adopted to represent internal consistency.

After a critical review of literature, the developed conceptual model can be presented as follows.

\subsection{Conceptual Framework}

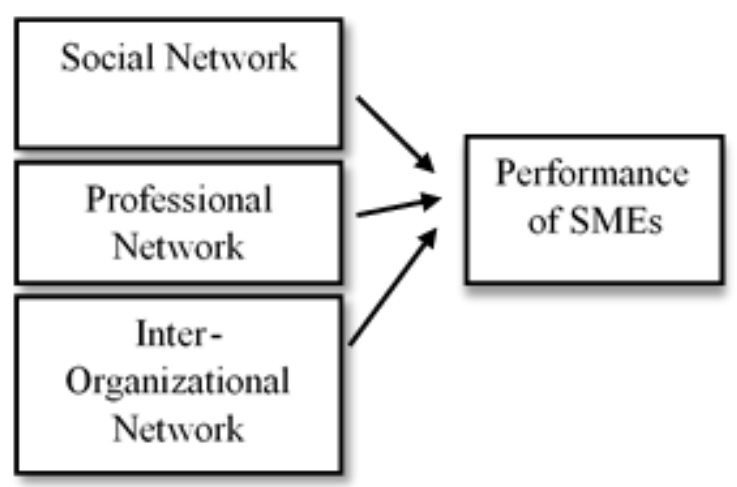

Figure 1. Conceptual Framework

\subsection{Hypotheses}

The researcher has developed following three hypotheses.

$\mathbf{H}_{1}$ : There is a positive \& significant impact of social network on the performance of manufacturing SMEs in Kurunegala district in Sri Lanka.

$\mathbf{H}_{2:}$ There is a positive \& significant impact of professional network on the performance of manufacturing SMEs in Kurunegala district in Sri Lanka.

$\mathbf{H}_{3}$ : There is a positive \& significant impact of inter-organizational network on the performance of manufacturing SMEs in Kurunegala district in Sri Lanka. 


\section{RESULTS}

The reliability of the measures of all constructs was assessed by using the Cronbach's alpha reliability coefficient and it indicated that all three variables alligned accepteable level of consistency more than 0.7 hence, it can be concluded that all the measures used in this study for the data collection are reliable instruments. Further testing assumptions of multivariate analysis of linearity, homoscedusticity, normality ensured the suitability of dataset. When considering multicollinearity, Varience Inflation Factor (VIF) of all variables and toletence values for all the observed variables are greater than 0.10 , which are in acceptable range. Table 1 illustrate the descriptive statistics results align with collected survey data

\section{Table 1. Descriptive Statistics}

\begin{tabular}{|l|c|c|c|c|c|}
\hline \multicolumn{1}{|c|}{ Variable } & N & Maximum & Minimum & Mean & $\begin{array}{c}\text { Std. } \\
\text { Deviation }\end{array}$ \\
\hline Social Networks & 383 & 5.00 & 3.29 & 4.1059 & .35517 \\
\hline Professional Networks & 383 & 5.00 & 2.83 & 3.8679 & .50293 \\
\hline $\begin{array}{l}\text { Inter-Organizational } \\
\text { Networks }\end{array}$ & 383 & 5.00 & 3.00 & 4.3784 & .43807 \\
\hline Performance & 383 & 4.83 & 3.04 & 4.1193 & .38491 \\
\hline
\end{tabular}

Source: Survey data, (2019)

The univariate analysis concluded that all variables have reported agreed levels by the respondent who entered to the survey.
Table 2. Results of Correlation Analysis

\begin{tabular}{|l|l|l|}
\hline Factors & $\begin{array}{l}\text { Performance } \\
\text { of SMEs }\end{array}$ & Sig. \\
\hline Social Network & 0.702 & 0.000 \\
\hline $\begin{array}{l}\text { Professional } \\
\text { Network }\end{array}$ & 0.547 & 0.000 \\
\hline $\begin{array}{l}\text { Inter- } \\
\text { Organizational } \\
\text { Network }\end{array}$ & 0.710 & 0.000 \\
\hline
\end{tabular}

Source: Survey data, (2019)

The table 2 indicated the Pearson correlation coefficient for the variables, where all the variables are positively related to the Performance of SMEs at a statistically significant level.

\section{Regression Analysis}

Multiple regression analysis was conducted to find out the impact of entrepreneurial network on the performance of manufacturing SMEs in Kurunegala district.

Table 3. Regression Analysis

\begin{tabular}{|c|c|c|c|c|c|}
\hline \multirow[b]{2}{*}{ Model } & \multicolumn{2}{|c|}{$\begin{array}{l}\text { Unstandardiz } \\
\text { ed } \\
\text { Coefficients }\end{array}$} & \multirow{2}{*}{$\begin{array}{l}\text { Standar } \\
\text { dized } \\
\text { Coeffic } \\
\text { ients } \\
\text { Beta } \\
\end{array}$} & \multirow[b]{2}{*}{$\mathrm{T}$} & \multirow[b]{2}{*}{ Sig. } \\
\hline & B & $\begin{array}{l}\text { Std. } \\
\text { Error }\end{array}$ & & & \\
\hline 1 (Constant) & 1.828 & .418 & & 4.373 & .000 \\
\hline Social Network & .706 & .272 & .493 & 5.344 & .000 \\
\hline $\begin{array}{l}\text { Professional } \\
\text { Network }\end{array}$ & .649 & .104 & .594 & 6.779 & .000 \\
\hline $\begin{array}{l}\text { Inter- } \\
\text { Organizational } \\
\text { Network }\end{array}$ & .782 & .170 & .292 & 3.326 & .000 \\
\hline
\end{tabular}

a. Dependent Variable: Performance of manufacturing SMEs

Source: Survey data, (2019)

Performance $=1.828+0.706 \mathrm{SN}+$ $0.649 \mathrm{PN}+0.782 \mathrm{IN}$ 
According to the above equation it indicates the beta value of Social Network as 0.706, which indicates that if the Social Network increase by one, the performance of manufacturing SMEs will increase by 0.706 units. This interpretation is true only if the other factors held constant. The significance level is 0.000 and it is less than 0.05 under the $95 \%$ significance level, so the alternative hypothesis is accepted while null hypothesis is rejected. Therefore, the researcher can conclude that social network positively and significantly impact on the performance of SMEs in Kurunegala district. Also Professional Network $((\beta=0.649, p=0.000)$ is positively impact on the Performance of manufacturing SMEs, whereas Inter-organizational Network $\quad(\beta=$ 0.782, $\mathrm{p}=0.000)$ has reported a positive impact on the Performance of manufacturing SMEs in Kurunegala district. According to the multiple regression analysis results, all the independent variables have a significant impact on the Performance of manufacturing SMEs in Kurunegala district. Hence all the Alternative hypotheses were accepted and null hypotheses were rejected, which indicates that the changes in Social network, Professional Network and Inter- Organizational Network can have a significant impact on the Performance of manufacturing SMEs in Kurunegala district. According to the regression results, the most influential variable can be identified as the Inter-Organizational Network factor as it has the highest beta value (Regression Coefficient) on the Performance of manufacturing SMEs.

\section{DISCUSSION}

According to the analysis, it was found that there is a significant Impact of entrepreneurial networks on the performance of manufacturing small and medium enterprises in Kurunegala district.

The first and main objective of the study was to investigate the Impact of entrepreneurial networks on the performance of manufacturing small and medium enterprises in Kurunegala district. Under the entrepreneurial networks, the impact of Social Network, Professional Network and Inter-organizational network on the performance of manufacturing small and medium enterprises in Kurunegala district were investigated. Hence, all together three hypotheses, were tested. Accordingly, Social Network, Professional Network and Interorganizational network investigated in this study were found to be good predictors of performance of manufacturing small and medium enterprises in Kurunegala district. In some previous researches, it is argued that entrepreneurial networks have been ignored by giving more attention to other factors. These results revealed that the role of entrepreneurial networks cannot be ignored in enhancing the performance of manufacturing SMEs. The positive relationships found in this study also supported to clear the ambiguity in findings because some researchers argue that the findings of previous studies were inconsistent. The results of this study proved that the above mentioned three entrepreneurial networks are important to enhance the 
performance of manufacturing SMEs in Kurunegala district.

\section{CONCLUSION}

The major purpose of this study is to investigate the impact of entrepreneurial networks on the performance of manufacturing small and medium enterprises in Kurunegala district.

The findings of the study are very useful for the small businesses in manufacturing sector to decide on what entrepreneurial networks to be developed in order to enhance the performance of their enterprises. Especially, inter-organizational networks need to be maintained with the government institutions, NGOs, banks, and other small business supporting institutes as those networks have the ability to help the SMEs in different ways such as providing financial assistance, providing information about new markets and products, and to provide the necessary workshops for small entrepreneurs about the different strategies that can be adopted when running their businesses. Also the findings of the study will be very useful for the government organizations, business community, policymakers, financial institutes and donor organizations to get an understanding about the need of their support to enhance the performance of the SMEs in Sri Lanka. Moreover, the perceptions of small business entrepreneurs on their networks to be developed can be understood while it gives an idea of the importance of being entrepreneurs.
Accordingly, the findings will serve the small business entrepreneurs to do a self-assessment and improving their networks to the expected level. The people who are willing to be entrepreneurs in future will also be benefitted with these findings by giving them a clear guidance of the importance of building entrepreneurial networks to enhance the performance of their businesses. The current study found that entrepreneurial networks are important determinants for the performance of SMEs. The actors in social networks, inter-organizational networks and professional networks are critical for an entrepreneur to become success in his/her business. However, the variables were limited only to three entrepreneurial networks. The findings of the current study provide signals that it is worth extending future studies for investigating other potential entrepreneurial networks to enhance the performance of SMEs.

\section{REFERENCES}

Aldrich, H., and Zimmer, C., (1986), 'Entrepreneurship through Social Networks', In Sexton, D. L., and Smilor, R., (eds.) The Art and Science of Entrepreneurship, Cambridge, pp. 3-23

Aldrich, H., Rosen, B., and Woodward, B.L., (1986), 'Social Behavior and Entrepreneurial Networks', Summarized in Frontiers of Entrepreneurship Research, Wellesley, MA, Center 
for Entrepreneurship Studies Babson Collage, pp. 239-40

Allesch. J., (1993), 'The Role of Supporting Institutions', in Abell, D. F., and Kollermeier, T., (eds.) 'Dynamic Entrepreneurship in Central and Eastern Europe Six Million New Entrepreneurs', Delooel Publisher, The Hague.

Anderson, B.A., Silver, B. D., and Abramson, P. R., (1988), 'The Effects of the Race of the Interviewer on Race-Related Attitudes of Black Respondents in SRC? CPS National Election Studies, Public Opinion Quarterly, Vol. 52, pp. 289-324

Birley, S., and Cromie, S., (1988), 'Social Networks and Entrepreneurship in Northern Ireland', Paper presented at Enterprise in Action Conference, Belfast (September).

Bridge, S., O’Neill, K., and Cromie, S., (1998), 'Understanding Enterprise, Entrepreneurship and Small Business', MacMillan Business: London.

Brown, B., and Butler, J. E., (1993), 'Networks and Entrepreneurial Development: the Shadow of Borders', Entrepreneurship and Regional Development, Vol. 5, pp.101-116.

Burt, R. S., (1982), 'Towards and Structural Theory of Action-A
Network Model of Social Stricture', Academic Press.

Butler, J., and Hansen, G. S., (1991), 'Network Evolution,

Entrepreneurial Success, and Regional Development', Entrepreneurship and Regional Development, Vol.3, pp.1-16.

Cromie, S., Birley, S., and Callaghan, I., (1994), 'Community Brokers: Their Role in the Formation and Development of Business Ventures', In Veciana, J. M., (ed), SMEs: Internationalization, Networks and Strategy, Publisher Aveburg, Singapore.

Donckels, R., and Lambrecht, J., (1995), 'Networks and Small Business Growth: An Explanatory Model', Small Business Economics, Vol. 7, pp. 273-89

Dubini, P., and Aldrich, H., (1991), 'Personal and Extended Networks are Central to the Entrepreneurial Process', Journal of Business Venturing, Vol. 6, pp. 305-13.

Gibb, A.A., (1993), 'Key Factors in the Design of Policy Support for the Small and Medium Enterprise (SME) Development Process: an overview', Entrepreneurship and Regional Development, Vol.7, pp.1-24.

Gibb, A.A., and Haas, Zoltan., (1996), 'Developing Local Support Services for Small Business development in Central and 
Eastern Europe - The Donor Challenge', Entrepreneurship and Regional Development, Vol.8, pp.197-216.

Greve, A., (1995), 'Networks and Entrepreneurship-An Analysis of Social Relations, Occupational Background, and Use of Contacts During the Establishment Process', Scandinavian Journal of Management, Vol. 11, No. 1, pp.1-24.

Hallen, L., and Johanson, J., (1989), 'Networks of relationships in International Industrial Marketing', JAI Press: Greenwich.

Hansen, E. L., (1995), 'Entrepreneurial Networks and New Organization Growth', Entrepreneurship Theory and Practice, Summer, pp. 7-19

ILO., (1995), 'Sri Lanka: Employment Promotion and the Development of Micro and Small Enterprises', Report of an ILO Mission Sponsored by the UNDP under Technical Support Services- 1, ILO, South Asia Multidisciplinary Advisory Team (SAAT), New Delhi, April,1995.

Johannisson, B., (1996), 'The Dynamics of Entrepreneurial Networks', Internet: http://www.babson.edu/entrep/fer /papers96/johannis.htm
Krejcie, R.V. and Morgan, D.W., 1970. Determining sample size for research activities. Educational and psychological measurement, 30(3), pp.607-610.

Lakshman, W. D., Vidanagama, S. S., Senanayake, S.M.P., Kaluarachchi, S., and Wettasinghe A., (1991), 'Changes in the Industrial Structure and the Role of Small and Medium Industries in Developing Countries: The Case of Sri Lanka', Tokyo: Institute of Developing Economies.

Lee , R., \& Jones, O. (2008). Networks, Communication and Learning during Business Start-up The Creation of Cognitive Social Capital. International Small Business Journal 26(5).

Lim, C. P., (1994), 'Framework Conditions for Effective Cooperation between

Government Sector Institutions (GSI) and Private Sector Institutions (PSI) in Small and Medium Enterprise (SME) Development'

Meller, P., and Marfan, M., (1981), 'Small and Large Industry: Employment Generation, Linkages, and Key Sectors', Economic Development and Cultural Change, Vol. 3.

Pfeffer, J., and Salancik, G. R., (1978), 'The External Control Organizations: A Resource 
Dependence Perspective', Harper and Row Publishers, New York.

Sadler, A., and Chetty, A., (2000), 'The Impact of Networks on New Zealand Firms', Journal of European Marketing, Vol. 9 (2), pp. $37-58$.

Sarder, J.H., Ghosh, D., and Rosa, P., (1997), 'The Importance of Support Services to Small Enterprise in Bangladesh', Journal of Small Business Management (JSBM), Vol. 35, No.2, (April), pp.26-36.

Szarka, J., (1990), 'Networking and Small Firms', Journal of International Small Business, Vol. 8, No.2, pp. 10-22.
Visser, E. J., (1997), 'The Significance of Spatial Clustering: External Economies in the Peruvian Small-Scale Clothing Industry', in van Dijk, M. P., and Rabellotti, R., (eds.) EADI Book Series 20, Frank Cass, London

Weick, K. E., (1991), 'The Nontraditional Quality of Organizational Learning', Organizational Science, Vol. 2, pp. 116-24.

Wellmilla, I., Weerakkody, W. A., \& Ediriweera, A. N. (2011). The Impact of Demographic Factors of Entrepreneurs on Development of SMEs in Tourism Industry in Sri Lanka . 